\title{
Survey on haemoglobin variants, $\beta$ thalassaemia, glucose-6-phosphate dehydrogenase deficiency, and haptoglobin types in Turks from Western Thrace
}

\author{
MUZAFFER AKSOY, ABDULLAH KUTLAR, FERDANE KUTLAR, GÜNÇAĞ \\ DINÇOL, SAKIR ERDEM, AND SEMRA BAŞTESBIHÇI \\ From the Unit of Haemolytic Anaemias and Chemical Haematotoxic Disorders, Scientific and Technical \\ Research Council of Turkey; and Section of Haematology, Department of Internal Medicine, Istanbul \\ Medical School, Capa, Turkey.
}

SUMMARY A total of 102 apparently healthy and randomly selected Turks who either immigrated $\stackrel{\circ}{工}$ from Western Thrace or were still living there were studied for haemoglobin variants, high $\mathrm{Hb} \mathrm{A}_{2} \beta \vec{\square}$ thalassaemia, G6PD deficiency, and haptoglobin types. The incidence of haemoglobins $\mathrm{S}$ and $\mathrm{O}$ 을 Arab were 2.9 and $3.9 \%$ respectively. The incidence of high $\mathrm{A}_{2} \beta$ thalassaemia was $10 \cdot 8 \%$ and $\stackrel{\text { क }}{\rightarrow}$ that of G6PD deficiency 5\%. The gene frequencies of $\mathrm{Hp} 1$ and $\mathrm{Hp} 2$ were 0.326 and $0.674, \overrightarrow{6}$ respectively.

The occurrence of numerous haemoglobinopathies, such as sickle cell anaemia, sickle cell $\beta^{+}$or $\beta^{\circ}$ thalassaemia, sickle cell-haemoglobin O Arab disease, and $\beta^{\circ}$ or $\beta^{+}$thalassaemia-haemoglobin O Arab combinations, prompted us to conduct a survey on abnormal haemoglobins, high $\mathrm{A}_{2} \beta$ thalassaemia, glucose-6-phosphate dehydrogenase (G6PD) deficiency, and the distribution of haptoglobin types in Turks from Western Thrace, a district in Greece close to the Turkish border.

The purpose of this paper is to report the results of this study.

\section{Material and methods}

A total of 102 apparently healthy and randomly selected Turks who either immigrated from Western Thrace to Turkey or still lived there were studied. Mostly they were from Komitine (Gümülcine), Thesalonokis (Selanik), and Xanthe (Iskeçe). The majority were students from several faculties of Istanbul University and a few were healthy relatives of Turkish immigrants from Western Thrace with different acquired haematological disorders. The group comprised 60 males and 42 females, whose ages varied between 13 and 68 years (mean 34 years). The methods for blood counts, electrophoretic analyses of the haemoglobin by starch gel and

Received for publication 8 June 1984. Accepted for publication 29 August 1984 cellulose acetate, quantitative estimations of haemoglobins $\mathrm{A}_{2}$ and $\mathrm{F}$, haptoglobin typing, and the screening method for G6PD activity have been described elsewhere. ${ }^{1}$ For the differentiation of abnormal haemoglobins with similar electrophoretic $\overline{0}$ mobility, such as haemoglobins S and D or haemoglobins $O$ Arab and $E$, the sickling test with $2 \%$ Na-metabisulfite and citrate-agar gel electrophoresis (Helena plates at $\mathrm{pH} 6 \cdot 2$ ) was used. ${ }^{2}$

\section{Results}

The results of haemoglobin analyses are given in table 1 . Three subjects with sickle cell trait were found among these people ( $\mathrm{Hb} \mathrm{S}$ : 36 to $41 \%$; $\mathrm{Hb}$ $\mathrm{A}_{2}: 2 \cdot 1$ to $2 \cdot 6 \% ; \mathrm{Hb} \mathrm{F}: 0$ to $\left.0 \cdot 1 \%\right)$. Four subjects with $\frac{7}{0}$ haemoglobin O Arab (32 to $35 \%$ ) were also found. Structural analysis of the $\mathrm{Hb}$ E-like fraction of one $\mathbb{N}$ of the patients, performed by liquid chromatography (HPLC) in the Protein Chemistry Laboratory of

TABLE 1 Distribution of abnormal haemoglobins and high $A_{2} \beta$ thalassaemia in 102 Turks from Western Thrace.

\begin{tabular}{lcr}
\hline & Subjects & $\%$ \\
\hline Normal & 82 & $80 \cdot 4$ \\
Sickle cell trait & 3 & $2 \cdot 9$ \\
Heterozygous haemoglobin O Arab & 4 & $3 \cdot 9$ \\
Heterozygous high $\mathrm{A}_{2} \beta$ thalassaemia & 11 & $10 \cdot 8$ \\
$\begin{array}{l}\text { Heterozygous normal } \mathrm{A}_{2} \boldsymbol{\beta} \text { thalassaemia or } \\
\quad \alpha \text { thalassaemia 1 }\end{array}$ & 2 & $2 \cdot 0$ \\
\hline
\end{tabular}


TABı.E 2 Distribution of haptoglobin types in 101 Turks from Western Thrace".

\begin{tabular}{|c|c|c|c|}
\hline Haptoglobin spes & Observed & Expected & $"$. \\
\hline $1-1$ & 10 & $10 \cdot 6$ & $10 \cdot 0$ \\
\hline $2-1$ & 45 & 4.3 .9 & +4.5 \\
\hline $2-2$ & 45 & 4.5 & 44.5 \\
\hline $0 \%$ & 1 & & $1 \cdot(1)$ \\
\hline
\end{tabular}

$\chi^{2}=0.061 . \mathrm{Hpl}=0.326 . \mathrm{Hp} 2=0.674$

"Haptoglobin typing was performed in 101 out of 102 Turks.

$\checkmark$ The subject with haptoglohin $O$ did not exhibit any findings of increased haemolysis.

the Medical College of Georgia, identified a lysyl residue at the aminoterminus of the tryptic peptide 13 of the $\beta$ chain where it replaced the normally occurring glutamic acid residue. This Glu $\rightarrow$ Lys substitution is characteristic of $\mathrm{Hb} \mathrm{O}$ Arab. The incidence of $\mathrm{Hb} \mathrm{O}$ Arab among Turks from Western Thrace was $3.9 \%$.

There were 11 heterozygotes with high $A_{2} \beta$ thalassaemia. The incidence of this type of $\beta$ thalassaemia among Turks from Western Thrace was $10 \cdot 8 \%$. In addition, two subjects showed a mild microcytic anaemia with normal levels of haemoglobins $\mathrm{A}_{2}$ and $\mathrm{F}$ and serum iron. Unfortunately, we did not perform globin chain synthesis studies and gene mapping of DNA. Therefore, we are unable to state whether these two subjects have heterozygous normal $\mathrm{A}_{2} \beta$ thalassaemia or $\alpha$ thalassaemia.

The incidence of G6PD deficiency among 60 males was $5 \%$. None of them was heterozygous for high $\mathrm{A}_{2} \beta$ thalassaemia or haemoglobins $\mathrm{S}$ and $\mathrm{O}$ Arab.

The results of the haptoglobin types are given in table 2. Proceeding from this, the gene frequencies were calculated as $\mathrm{Hp} 10.326$ and $\mathrm{Hp} 20.674$. One subject had $\mathrm{HpO}$.

\section{Discussion}

In this survey 20 subjects among 102 apparently healthy Turks from Western Thrace had either an abnormal haemoglobin variant or a heterozygous form of $\beta$ thalassaemia.

\section{HAEMOGLOBIN S}

Apart from Eti-Turks, an Arabic speaking population living in south western Turkey, the incidence of $\mathrm{Hb} \mathrm{S}$ in Turks is generally very low, ranging between 0.20 and $0.37 \%$, according to three studies performed. ${ }^{3-5}$ Despite this, there are some foci of this abnormal haemoglobin in Turkey. ${ }^{1}$ " In the present study an incidence of $\mathrm{Hb} \mathrm{S}$ of $2.9 \%$ was found among Turks from Western Thrace.
HAEMOGLOBIN OARAB

The incidence of $\mathrm{Hb} \mathrm{O}$ Arab among Turks from Western Thrace is $3 \cdot 9 \%$. Hb O Arab has been found in Arabs living in Israel, ${ }^{7}$ in Egypt, ${ }^{8}$ in Aden. ${ }^{9}$ in Sudan, ${ }^{11}$ in Turks, ${ }^{11}$ in Turkish Cypriots, ${ }^{12}$ and in Negroes from Jamaica, ${ }^{13}$ and the United States. ${ }^{14}$ Furthermore, a total of 17 families with $\mathrm{Hb} \mathrm{O}$ Arab, mostly associated with heterozygous $\beta$ thalassaemia, and one with the homozygous form, have been reported from Bulgaria. "Fourteen of them lived in Burgas, Eastern Thrace, and the remaining three were from other regions of Bulgaria. Additionally, a few families with $\mathrm{Hb} \mathrm{O}$ Arab have been found in Romania, ${ }^{16}$ Yugoslavia, ${ }^{17}$ and Hungary. ${ }^{18}$ Sharma $e t$ $a l^{19}$ described a family with $\mathrm{Hb} \mathrm{O}$ Arab $\beta^{\circ}$ thalassaemia of Greek origin living in Australia, but they noted that the family was of Turkish descent and came from Komitine. Therefore, this family was similar to those presented here. Up to the present, we have studied nine families with $\mathrm{Hb} O \mathrm{Arab} \beta^{\circ}$ or $\beta^{+}$ thalassaemia, one family with sickle cell-Hb O Arab disease ${ }^{20}$ and one family with heterozygous $\mathrm{Hb} \mathrm{O}$ Arab. All were Turkish immigrants from Western Thrace. It seems most likely that at present there are two foci of $\mathrm{Hb} \mathrm{O}$ Arab in Eastern Europe: one comprises Turks from Western Thrace and the second comprises Bulgars mainly living in the district of Burgas. However, it is difficult to explain the absence of $\mathrm{Hb} O$ Arab in Greeks living in Western Thrace. This problem needs further investigation.

\section{HIGH A $\beta$ THAL ASSAFMIA}

The incidence of this type of $\beta$ thalassaemia among Turks from Western Thrace is as high as $10 \cdot 8 \%$. According to Arcasoy and Çavdar ${ }^{21}$ the incidence of high $\mathrm{A}_{2} \beta$ thalassaemia in Turkey is $2 \cdot 1 \%$. Furthermore, as pointed out by Dinçol et al, ${ }^{22}$ although high $A_{2} \beta$ thalassaemia has been found in every region of Turkey, it is rather more frequently encountered in the western part of the country. The present study confirms this.

HAPTOGLOBIN TYPES

The distribution of haptoglobin types among Turks from Western Thrace was a little different from that found in Turkish people in general (table 2). The percentage of $\mathrm{Hp} \mathrm{1-1}$ was a little higher than found in Turks in general: $10 \%$ and $7.5 \%$ respectively. ${ }^{23}$ Furthermore, Hpl gene frequency among Turks from Western Thrace was also high when compared with those of other Asiatic populations, including Turks in general: 0.326 and 0.265 respectively. $\mathrm{Hpl}$ gene frequency among Asiatic people varies between $0 \cdot 21$ and $0 \cdot 31 .{ }^{24}$ 
G6P D DEFICI EN CY

The incidence of G6PD deficiency in Turks from Western Thrace was found to be moderately high at $5 \%$. Contrary to this, the overall incidence of G6PD deficiency in Turks in general is low at $0 \cdot 6 \%,{ }^{1}$ but there are some foci of comparatively high incidence of this enzyme deficiency. ${ }^{1}$

We are indebted to Professor T H J Huisman for the structural analysis of haemoglobin $\mathrm{O}$ Arab.

\section{References}

I Aksoy M, Dinçol G, Erdem Ş. Survey on haemoglobin variants, $\beta$-thalassaemia, glucose-6-phosphate dehydrogenase deficiency and haptoglobin types in Turkish people living in Manavgat. Serik and Boztepe (Antalya). Hum Hered 1980;30:3-6.

2 Huisman THJ, Jonxis JHP. The hemoglobinopathies. Techniques of identification. New York: Marcel Dekker, 1977:82-112.

${ }^{3}$ Aksoy M. Hacmoglobin S and E in Turkish people. Nature 1962;193:786-7.

+ Çavdar AO, Arcasoy A. Thalassemia and abnormal hemoglobins in Turkey. In: Aksoy M, ed. International Istanbul symposium on abnormal hemoglobins and thalassemia. Ankara: TÜBÏTAK Publications, 1975:337-42.

5 Dinçol G, Aksoy M, Dinçol K, Kutlar A. A survey for hemoglobin variants and high $\mathrm{A}_{2} \beta$-thalassemia in 1000 Turks In: Aksoy M, Huisman THJ, eds. North Cyprus symposium on thalassemia and abnormal hemoglobins, 1984 (in press).

- Aksoy M, Dinçol G, Erdem S. Sickle cell syndromes in Turkey. New Istanbul Contribution to Clinical Science 1978;12:185-200.

${ }^{7}$ Ramot B, Fishers S, Remez D, et al. Haemoglobin O in an Arab family. Br Med J 1960;ii:1262-4.

${ }^{x}$ Hoerman KC, Kamel K, Awny AY. Haemoglobin E in Egypt. Nature 1960;189:69-70.

${ }^{9}$ Barakat A. Morenge-Rowe AJ, Gaffncy PJ, et al. Haemoglobin O Arab in Egypt and Aden: possible errors resulting from the use of haemoglobin variants as genetic markers in population surveys. Z Morphol Anthropol 1967;59:100-3.

11) Vella F, Beale D, Lchmann H. Haemoglobin O Arab in Sudanese. Nature 1966;209:308-9.

"Prozorova-Zamani V, Özsoylu \$, Aksoy M, et al. Hb E and $\mathrm{Hb}$ $\mathrm{E}$ like variants in individuals from Turkey. Hemoglobin 1981;5:743-6.
12 Cin S. Akar N, Arcasoy A, Çavdar AO, Dedeoğlu S. Hacmoglobin O Arab (B121 Glu-Lys) in Turkish Cypriot population. J Med Genet 1984;21:158.

13 Milner PF, Milner C, Grey R, et al. Hemoglobin O Arab in four negro families and its interaction with hemoglobin $\mathrm{S}$ and hemoglobin C. $N$ Engl J Med 1970;283:1417-25.

${ }^{14} \mathrm{Kini} \mathrm{KR}$, Warrier RP, Maeda K, et al. Hacmatological studies in haemoglobin SO Arab and CO Arab disease. Abstracts ISH European and African Div, 6th meeting, Athens, 1981:182.

15 Kantchev KN. Tcholakov BN, Casey R. et al. Twelve families with $\mathrm{Hb} \mathrm{O}$ Arab in the Burgas district of Bulgaria. Observations on sixteen examples of $\mathrm{Hb} \mathrm{O}$ Arab- $\beta^{\circ}$ thalassacmia. Hum Genet 1975;26:93-7.

16" Bratu V. Predescu C. Patea N, et al. Hemoglobin O Arabia: considerations on the first nine cases discovered in Romania. Med Interne 1975;13:141-5.

17 Efremov GD, Sadikaris A, Stajancov A, et al. Homozygous hemoglobin O Arab in a gypsy family in Yugoslavia. Hemoglobin 1977;1:389-94.

${ }^{1 \times}$ Horanyi M, Szelenyi J, Rona G, et al. Hacmoglobin O Arab beta-thalassacmia and glucose-6-phosphate dehydrogenase deficiency in a Hungarian family. Folia Haematol (Leipz) 1980;107:654-60.

1" Sharma RS, Williams L. Baptist NG, et al. Hacmoglobin O and haemoglobin O Arab thalassaemia in families of Greek origin. Pathology 1976;8:89-93.

20 Aksoy M. Pala Ö, Saya A, Erçil G. Sickle-hemoglobin O Arab disease in a Turkish family from Western Thrace. In: Aksoy M, Huisman THJ, eds. North Cyprus symposium on thalassemia and abnormal hemoglobins, 1984 (in press).

21 Arcasoy A, Çavdar AO. Thalassemia incidence in Turkey. In: Aksoy M, ed. Symposium on thalassemia. Ankara: TÜBIITAK Publications, No 540, 1982:13-9.

22 Dinçol G, Aksoy M, Erdem Ş. Beta-thalassaemia with increased haemoglobin $A_{2}$ in Turkey. Study in 164 thalassaemic heterozygotes. Hum Hered 1979;29:272-8.

${ }^{23}$ Erdem Ş, Aksoy M. A note on the distribution of haptoglobin types in Turkey. Hum Hered 1975:25:18-9.

24 Giblett ER. Genetic markers in human blood. Oxford: Blackwell, 1969:93-100.

Correspondence and requests for reprints to Dr M Aksoy, Section of Haematology, Department of Medicine, Istanbul Medical School, Capa, Istanbul, Turkey. 